\title{
拡張現実感による照明シミュレーションのための \\ 色票を用いた光学的整合性の実現手法 \\ PHOTOMETRIC REGISTRATION USING A COLOR CHART FOR LIGHTING SIMULATION IN AUGMENTED REALITY
}

\author{
福田知弘*, 林緯 政**, 矢吹信喜*** \\ Tomohiro FUKUDA, Weicheng LIN and Nobuyoshi YABUKI
}

\begin{abstract}
This research presents the photometric registration of a 3-Dimensional Computer Graphics (3DCG) and live video image at the time of simulating lighting design in Augmented Reality (AR). First, a color chart system with three brightness levels and a brightness measurement system were developed. Secondly, the accuracy of the 3DCG model with illumination effects was verified. Finally, the 3DCG model with illumination effects was input to an AR system in which a color chart system was installed. Consequently, the brightness of the 3DCG model and the live video image were equalized. This experiment showed that the proposed system was effective.
\end{abstract}

Keywords : Augmented Reality, lighting design, lighting simulation, illuminance, photometric registration 拡張現実感, 照明デザイン, 照明シミュレーション, 照度, 光学的整合性

1. はじめに

\section{1 視覚化に着目した照明シミュレーション手法と課題}

建築・都市分野において，安全性，機能性，美観性，快適性，省 エネ，低炭素社会，脱光害等に配慮した最適な照明環境を実現する ためには, 計画・設計・施工の各段階で周辺の環境も含む照明シミ ユレーションを行い, 予測内容を視覚化する必要がある.このため, 伝統的には模型や手書きパースが使用されてきたが, 再現性・正確 性・操作性等の観点から一定の限界がある。それらの課題解決に向 けて，コンピュータシミュレーション技術が開発されており，3DCG (3-Dimensional Computer Graphics) 静止画, 3DCG アニメーショ ン, VR（Virtual Reality：人工現実感）が実用化されてきた.

3DCG 静止画は，3 次元仮想空間上に 3 次元形状や質感, 光源を定 義し（以上、3DCG モデル），プリレンダリング処理によりある視点 からの画像を作成する手法である. 3DCG アニメーションは, 連続的 に作成された $3 \mathrm{DCG}$ 静止画を時系列に沿って慗げた動画像である.こ れらの手法は，一定の精度を得るための計算時間を確保することが 可能であり, 高いシミュレーション精度を得ることが可能となる ${ }^{1)}$. 一方で，検討会議中に視点や照明設計等のパラメータをその場で変 更して，異なる視点や代替案を実時間で再生成することは困難であ る。

VR は, 3DCG モデルをリアルタイムレンダリング処理により動画像
を作成する手法である.実時間で計算する必要があるため,一般に, シミュレーション精度は $3 D C G$ 静止画より劣る. しかしながら, 実時 間性を確保しているため, リアルタイムに視点位置, 視線方向, 光環境条 件を変更して計算できる注 1)。そのため, 照明設計検討の初期段階に多 数のパラメータを変更して大まかな検討を行う際に有効であると考えられ る ${ }^{2)}$ 。一方，3DCG 静止画，3DCG アニメーション，VR に共通する課 題として,シミュレーションすべき全ての情報を 3DCG モデルとして 仮想空間上に定義する必要がある（図 1 （左））。すなわち，設計 対象物のみならず，設計対象物の周辺環境を表現する必要があり， 現状の環境調查と照明効果付き $3 \mathrm{DCG}$ モデル化に多大な労力が必要 とされてきた。

このような背景からビデオカメラ等により取得される実写映像と 仮想空間の情報とを重畳表現可能な AR (Augmented Reality : 拡張 現実感）に関する研究が進められている3345)(6)778)99.AR を応用すれ ば, 設計対象物以外の 3DCG モデルを構築する代わりに実写映像を用 いることにより，設計対象物を現状の環境中に包含してシミュレー ションでき, 現状の環境を $3 D C G$ モデル化する工数と手間の削減が期 待できる（図1（右））。

AR では実写映像と $3 D C G$ モデルとの幾何学的整合性，光学的整合 性, 時間的整合性に関する議論がなされている. 本研究では, この うち照明シミュレーションと関わりの深い光学的整合性に着目寸る。

\footnotetext{
本論文は，第34回情報・システム・利用・技術シンポジウム論文集 $(\text { 報告 })^{23)}$ ， 日本建築学会近畿支部研究報告集 ${ }^{24)}$ に扔いて発表した論文に加筆・修正したものである。 大阪大学大学院工学研究科環境・エネルギー工学専攻Ｉ Assoc. Prof., Division of Sustainable Energy and Environmental Engineering, Graduate 准教授. 博士 (工学)

** 袁宗南照明設計事務所 工修

*** 大阪大学大学院工学研究科環境・エネルギー工学専攻 教授・Ph. D. School of Engineering, Osaka University, Dr. Eng. J.Y. Light Design, M. Eng.

Prof., Division of Sustainable Energy and Environmental Engineering, Graduate School of Engineering, Osaka University, Ph. D.
} 

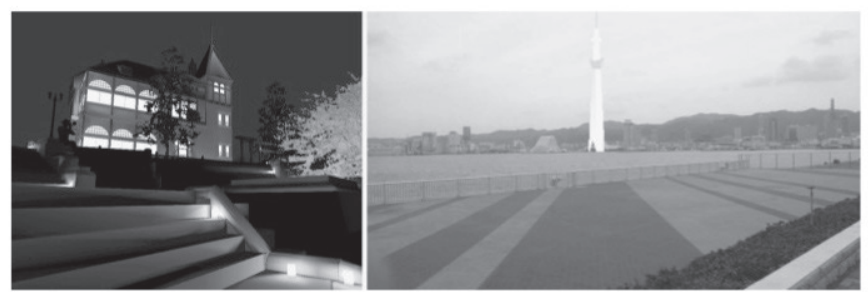

図 1 周辺環境を含む夜景 VR の例（左）, 昼景 AR の例 ${ }^{9)}$ (右)

照明効果付き $3 \mathrm{DCG}$ モデルと実写映像とをAR上で重畳させる際には, それらの光学的特性を一致させることが重要な課題である. すなわ ち, 3DCG モデルの測光量と実写映像のそれとが同一である場合に, AR 画面上で 3DCG モデルと実写映像の表示が同一となるように実現 するための手法が望まれる. このような, 光学的整合性の実現手法 に関する既往研究について次節で整理する.

\section{2 既往研究の整理}

AR における光学的整合性の実現手法の研究動向について整理す る. 池内ら ${ }^{10}$ は, 画像列から反射モデルの係数を抽出し, これを物 体表面に蓄積して任意光源・任意視点での画像を合成することを可 能とするモデルベース法を示した，神原ら ${ }^{11}$ は，幾何学的整合性と 光学的整合性を同時に解決するために正方マーカと鏡面球を組み合 わせた 3 次元マーカを利用して違和感のない AR 環境の構築を試みた. 冨手ら ${ }^{12}$ は, 現実の影と光学的な整合性を保って仮想の影を描画す る手法を検討した. 角田ら ${ }^{13)}$ は, シーンの 3 次元モデル周辺に仮想 的な平面上の物体を配置し，この平面群に対して物体の影を表す画 像をテクスチャマッピングすることで実光源環境に対応した物体の ソフトシャドウを高速に表現する手法を提案している。小川ら 14) は，正方形マーカを固定する押しピンが作る影を手がかりとして， 光源を正確に推定寸る手法を検討した。仁科ら ${ }^{15)}$ は, 仮想物体の陰 影のみならず写り込みを再現するため, 八イダイナミックレンジで 撮影した画像から光源環境推定を行う手法を検討した。これらの報 告は, 実空間に存在する照明環境や陰影を手掛かりに光源環境マッ プを作成して 3 DCG モデルに合成する試みである。一方, 本研究が対 象とするような照明設計分野に AR を応用する場合, 照度等の測光量 と視覚化された AR 映像との関係も確認可能であることが必要とさ れる. 上述した既報では測光量についての記述は見られず照明設計 ツールとしての使用に課題が残る。

\section{3 本研究の目的}

一方，実際の照明シミュレーションの現場において，実物の光源 と 3DCG モデルを両方とも用意することは稀である. すなわち, BDCG モデルと実写映像の測光量が同值になっているかを確認することは 実質困難であり，何らかの手法により支援する必要がある. 興味深 い既往研究として, 篠田ら ${ }^{16)}{ }^{17)}$ は, 空間の明るさ感を測定する手法 として色モード境界輝度測定法を提案している. これは, 同じ輝度 を持つパッチ (視対象) を明るさ感の異なる空間に入れると, 空間 の明るさ感の大きさに応じて知覚されるパッチの明るさが異なると いう人間の視覚特性を応用して「空間の明るさ感」を定量化する手 法である. 本研究では, 篠田ら ${ }^{16)}$ が提案したようなパッチを媒介と して, 実物の光源により発生する照度と $3 \mathrm{DCG}$ モデルにより発生する それとを同值化させることが可能になると考えられる。

そこで本研究は, AR で照明シミュレーションを行う際に必要とな
る, 3DCG モデルと実写映像との光学的整合性を色票を媒介として実 現することを目的とした.

本研究で開発する AR システムの位置づけを述べる，AR は実時間 性を確保するため計算精度は高くない，そのため，精度の低い計算 結果を考慮の上で設計内容をある程度正しく予測することが可能な ユーザが対象となる，具体的には，照明設計者自身の検討や，照明 の専門家同士による検討の場での使用が考えられる．また活用の段 階であるが，AR システムは，VR と同様，実時間性を確保しているた め, リアルタイムに視点位置, 視線方向, 光環境条件を変更して再 計算できる. そのため, 照明設計検討の初期段階に多数のパラメー 夕を変更して大まかな検討を行う際に有効であると考えられる.

\section{2. 照明シミュレーションのための AR システムの構築}

\section{1 構築した AR システム}

AR システムは既往研究 ${ }^{6) 18)}$ の成果を基に, 人工マーカ方式とし, ARtoolKit ${ }^{19)}$ を基本ライブラリとして構築する．人工マーカは一般 に紙等を材料とするが，本研究が対象とする夜間の場合，使用する 空間の照度が低く, 人工マーカの認識が困難である可能性が高い. そこで,ノートPC の画面上にマーカを表示させる内照式のマーカと した.

AR システムのフローを図 2 に示す. まず, 3DCGソフトウェア上で, 照射面となる床や壁等の形状, 色 (反射率を含む), テクスチャを含 む $3 D C G$ モデルの定義, 及び，光束，色温度（RGB）, 配光曲線を含む 光源モデルの定義を行った後,テクスチャレンダリングを行い, VRML

(Virtual Reality Modeling Language) 形式として出力する. 結果, 照明効果付きテクスチャを含む $3 \mathrm{DCG}$ モデルが生成される. 次に, AR システムに $3 \mathrm{DCG}$ モデルを入力し, web カメラで内照式の人工マーカ をキャプチャして, 画面上に $3 D C G$ モデルと実写映像とを重畳させて AR 表示する.

\section{2 色票システムの設計}

本研究では白色光源を対象とする. 同值化させるパッチは色票と し，3DCG モデルとして表示される色票 $\mathrm{CS}_{\mathrm{cg}}$ と実空間に配置され web カメラにキャプチャされて実写映像としてAR表示される色票 $\mathrm{CS}_{\mathrm{video}}$ を準備する. 色票 $\mathrm{CS}_{\mathrm{cg}}, \mathrm{CS}_{\mathrm{video}}$ はいずれも, 使用する空間の照度が 低くても対応可能であるよう,いずれもノートPC の画面上に表示さ せる，そのため，デジタル画像で用いられる画素階調值（RGB をそ れぞれ Bbit 表現した場合の階調值の平均值. 本研究では白色光源を 対象とするためグレースケール画像となり $\mathrm{R}=\mathrm{B}=\mathrm{G}=$ 平均值である）に ついて, 3 段階の明るさ ( $R G B$ 值), 白 ( $R=G=B=255), 50 \%$ 灰 $(R=G=B=127)$, 黒（ $\mathrm{R}=\mathrm{G}=\mathrm{B}=0$ ）を準備する（図 3）。 寸なおち, 各 RGB 值において, 色票 $\mathrm{CS}_{\mathrm{cg}}$ の $\mathrm{RGB}$ 值 $\mathrm{RGB}_{\mathrm{cg}}$ と, 色票 $\mathrm{CS}_{\mathrm{video}}$ の RGB 值 $\mathrm{RGB}_{\mathrm{video}}$ が同值であ れば，光学的整合性は実現していると考えられる.

光学的整合性の実現に影響を与えるパラメータを整理する．照明 シミュレーション時には, 光源は点光源として定義され, 光源の光 束, 色温度, 配光曲線をパラメータとして使用する. 3DCG モデルの 色や反射率は実空間と同一にする必要がある. 実物の光源は web カ メラを通じて AR 表示されるため, 色票 $\mathrm{CS}_{\mathrm{video}}$ を表示するディスプレ イの輝度, web カメラのパラメータである明るさ, コントラスト, ガンマ, 露出等が RGB 值に影響を与える. 尚, 色票 $\mathrm{CS}_{\mathrm{cg}}$ の各 RGB 值 $\mathrm{RGB}_{\mathrm{cg}-255}, \mathrm{RGB}_{\mathrm{cg}-127}, \mathrm{RGB}_{\mathrm{cg}-0}$ は, パラメータの影響を受けないため, 


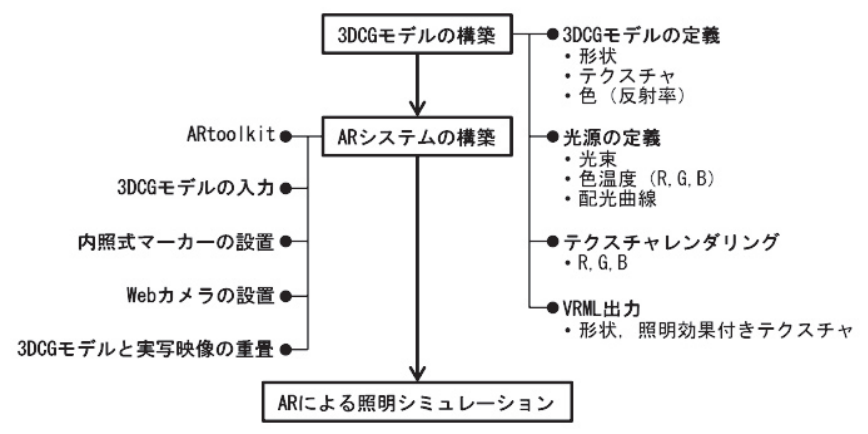

図 2 AR システムのフロー

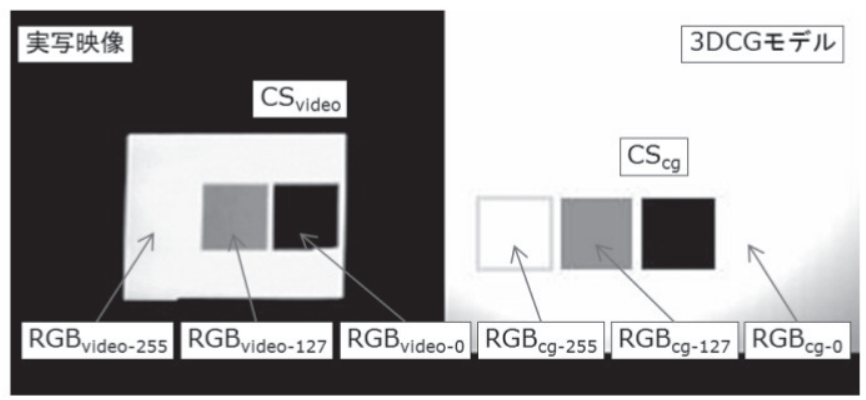

図 3 AR 画面上に表示した色票システム

常に, $\mathrm{RGB}_{\mathrm{cg}-255}=\mathrm{R}=\mathrm{G}=\mathrm{B}=255, \mathrm{RGB}_{\mathrm{cg}-127}=\mathrm{R}=\mathrm{G}=\mathrm{B}=127, \mathrm{RGB}_{\mathrm{cg}-0}=\mathrm{R}=\mathrm{G}=\mathrm{B}=0$ と なる.

\section{3 RGB 值計測システムの開発}

色票システムでは，3 段階の RGB 值 $\mathrm{RGB}_{\mathrm{cg}}$ と RGB 值 $\mathrm{RGB}_{\mathrm{video}}$ とを同 值化することが重要となる。 一方, 前節で述べたように, この同值 化の作業には多数のパラメータが存在するため, 短時間に数多くの パラメータの組み合わせを試行できることが望ましい。そのため, $\mathrm{RGB}_{\mathrm{cg}}$ と $\mathrm{RGB}_{\mathrm{video}}$ を効率的に計測できる $\mathrm{RGB}$ 值計測システムを開発し た.

RGB 值計測システムのフローを図 4 に示す. AR 画面上に表示され た各 RGB 值の色票 $\mathrm{CS}_{\mathrm{cg}}$ と色票 $\mathrm{CS}_{\mathrm{video}}$ を順に選択する. 選択された色 票の中心点の周囲 64 画素を抽出する. 抽出された画素群の各 $\mathrm{V}$ 值を 取得し, 求めた平均值を色票の RGB 值 $R_{G B} B_{\mathrm{cg}-255}, \mathrm{RGB}_{\mathrm{cg}-127}, \mathrm{RGB}_{\mathrm{cg}-0}$,

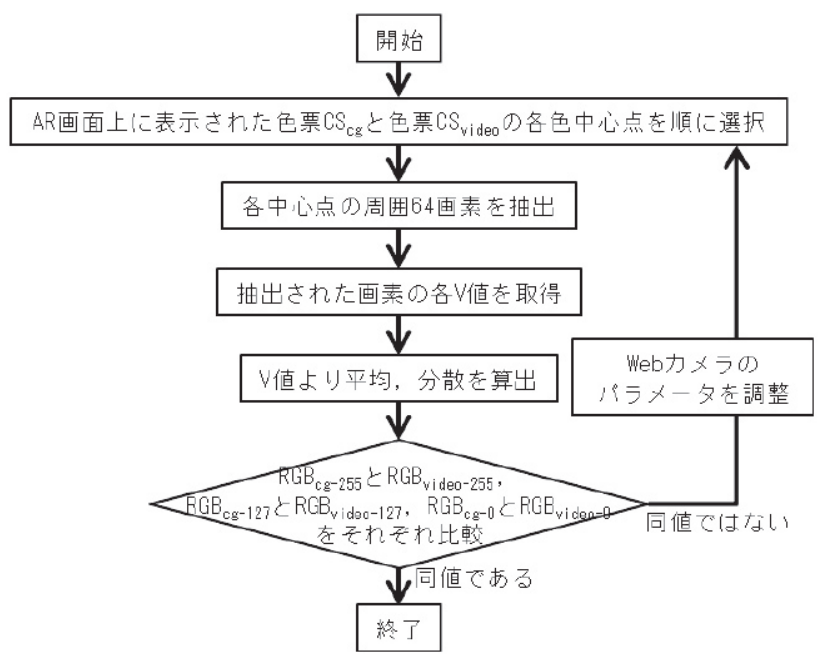

図 4 RGB 值計測システムのフロー
$\mathrm{RGB}_{\mathrm{video}-255}, \mathrm{RGB}_{\mathrm{video}-127}, \mathrm{RGB}_{\mathrm{video}-0}$ とする. 次に, $\mathrm{RGB}_{\mathrm{cg}-255}$ と $\mathrm{RGB}_{\mathrm{video}-255}$, $\mathrm{RGB}_{\mathrm{cg}-127}$ と $\mathrm{RGB}_{\mathrm{video}-127}, \mathrm{RGB}_{\mathrm{cg}-0}$ と $\mathrm{RGB}_{\mathrm{video}-0}$ の值をそれぞれ比較し, 差 がある場合にはパラメータを変更して再計測を行う。 RGB 值計測シ ステムは, OpenCV (Open Source Computer Vision) ${ }^{20)}$ の各ライブ ラリを使用して開発した。

\section{3. 照明効果付き $3 D C G$ モデルの精度検証}

3. 1 3DCG 照度分析の性能確認

\section{(1) 実験概要}

AR 上に照明設計モデルを表示するために照明効果付き $3 \mathrm{DCG}$ モデ ルを作成する必要がある。まず，この 3DCG モデルが照明光学理論を どの程度再現可能であるかを確認する。本研究で使用した光源は, パナソニック製 LED 電球（LDA7D-A1）である。これは照明シミュレ ーションに必要な, 光束 $(5701 \mathrm{~m})$, 色温度 $(6700 \mathrm{~K})$, 配光曲線が入 手可能であるためである. 3DCG モデル作成と照度分析には Autodesk 製 3ds MAX DESIGN 2010 (以下，3dsMAX）の照明分析アシスタント を使用した。実験内容は以下の通りである.

、光源よりある一定の距離 $h$ に作業面上を定義し, 作業面上の照 度を照度計算式並びに 3 DCG 照度分析機能によりそれぞれ計算す る. hは, $30 \mathrm{~cm}, 50 \mathrm{~cm}, 100 \mathrm{~cm}$ とした。

・照度計算式について述べる. 図 5 (左) のように, 点光源のある 方向の光束が $I$ である時, $h$ の距離における光の方向に垂直な面 上 $\mathrm{P}$ 点の照度 $E$ は逆二乗の法則により, 式 (1) となる.

$$
E=I / h^{2}
$$
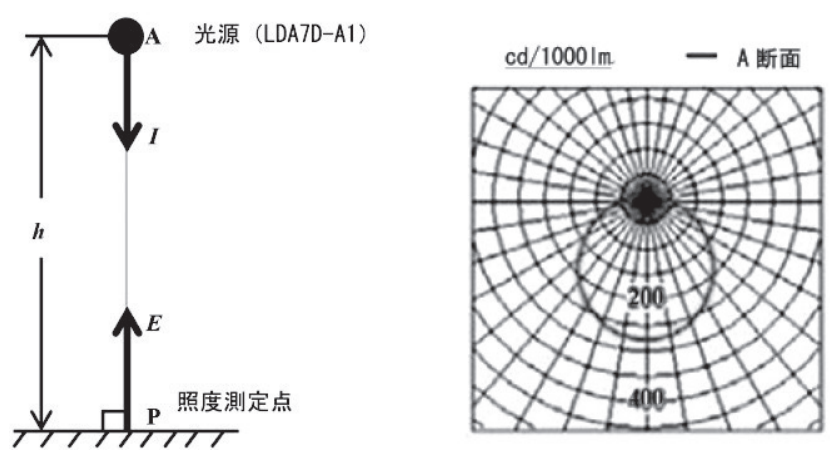

図 5 逆二乗の法則 (左) と光源の配光曲線 (右)

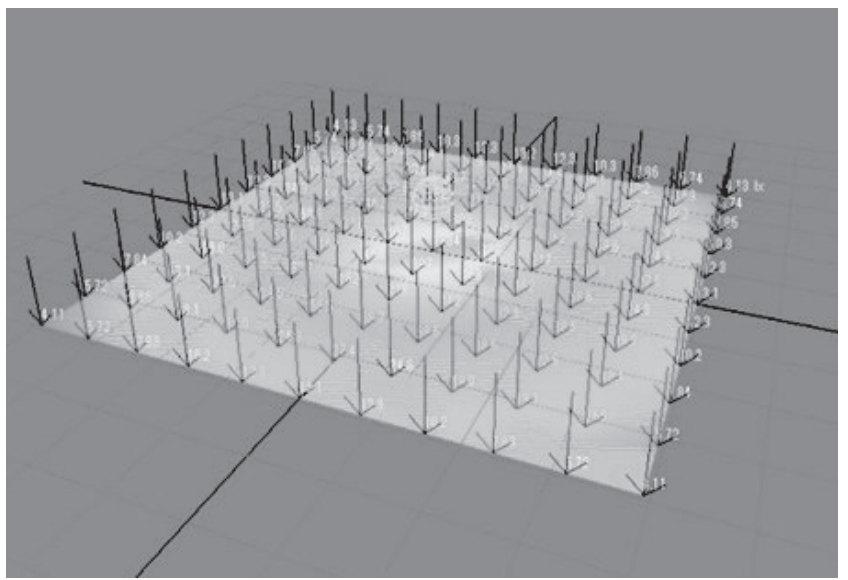

図 $63 \mathrm{dsMAX}$ の照明分析アシスタント画面 
- 光度 $I$ は光源の配光曲線 (図 5 (右) ) より読み取り, $h$ に, $30 \mathrm{~cm}$, $50 \mathrm{~cm}, 100 \mathrm{~cm}$ を代入して, $E_{F-30}, E_{F-50}, E_{F-100}$ を求める.

・ 3dsMAX 上に, 図 5 (左) と同じ 3DCG モデルを作成し, 距離 $h$ 上 空に光源の光束と配光曲線 (. i es) を付与した点光源モデルを 配置して照度解析を行い， $E_{C G-30}, E_{C G-50}, E_{C G-100}$ を得る（図 6).

計算結果を比較して, 3DCG 照度分析の性能を確認する.

\section{(2) 結果}

照度計算式並びに 3 DCG 照度分析による照度值を表 1 に示す. 結果, 照度計算式で得られる照度值 $E_{F-30}, E_{F-50}, E_{F-100}$ と, $3 \mathrm{DCG}$ 照度分析で 得られる照度值 $E_{C G-30,} E_{C G-50}, E_{C G-100}$ は同值である. すなわち, $3 \mathrm{DCG}$ 照度分析機能の性能は照度計算式に基づいているといえる.

表 1 3DCG 照明分析の性能確認結果

\begin{tabular}{c|c|c|c|c}
\hline \multicolumn{2}{c|}{ 測定距離 $(\mathrm{cm})$} & 30 & 50 & 100 \\
\hline \multirow{2}{*}{ 照度 $(1 \mathrm{x})$} & 照度計算式 & 1734 & 624 & 156 \\
\cline { 2 - 5 } & 3DCG 照度分析 & 1734 & 624 & 156 \\
\hline \multicolumn{2}{c}{ 照度計算式-3DCG 照度分析 } & 0 & 0 & 0 \\
\hline
\end{tabular}

\section{23 DCG 照度分析と実測の比較}

\section{(1) 実験概要}

次に, 3DCG 分析により作成される 3DCG モデルと実物の光源の照 度值との比較を行う注 2). 以下の 2 種類の実験を実施した（図 7).

a) 実験(1)

室内にて実物の光源を 3.1 節と同様に, $h$ が $30 \mathrm{~cm}, 50 \mathrm{~cm}, 100 \mathrm{~cm}$, $150 \mathrm{~cm}, 200 \mathrm{~cm}$ の地点で, 照度を測定した注3)。

b) 実験(2)

実験(1)では垂直距離 $h$ に関する照度を測定したが，実験(2)では現 実の設計により近い条件を想定する。 そのため, 実物の光源と照射 面 (壁) との距離 $d$ を $50 \mathrm{~cm}, 100 \mathrm{~cm}$ と変化させ, 床面に設置された 実物の光源の水平位置から垂直方向 $0 \sim 100 \mathrm{~cm}$ の範囲で照度を測定 した注4).
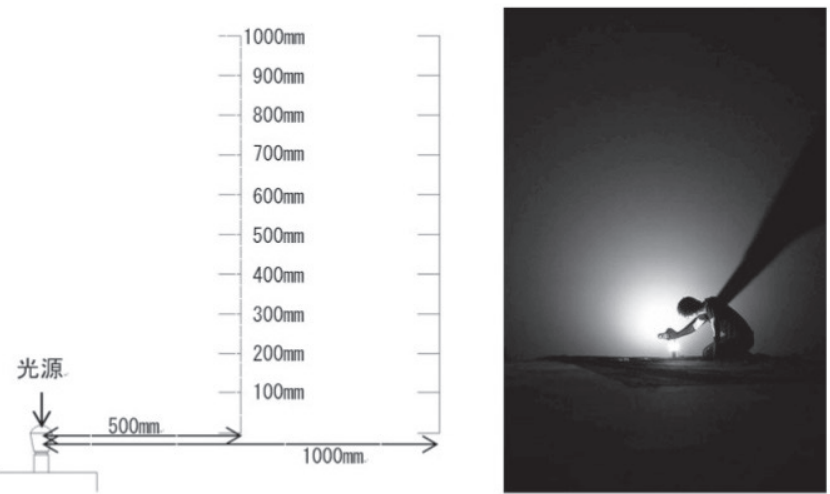

図 7 実験(2)の測定方法(左) と実験風景(右)

\section{(2) 結果}

a) 実験(1)

結果を表 2 に示す. 結果, 実測值の方が 3DCG 照度分析による照度 值より全て高くなった. 実測值の照度は 3DCG 照度分析より 14 52\% 高い.

b) 実験(2)

3DCG 照度分析と実測值の比較結果を図 8,9 亿示す。結果, 実験
表 2 3DCG 照度分析と実測との比較（実験(1)）

\begin{tabular}{c|c|c|c|c|c|c}
\hline \multicolumn{2}{c|}{ 測定距離 $(\mathrm{cm})$} & 30 & 50 & 100 & 150 & 200 \\
\hline \multirow{2}{*}{$\begin{array}{l}\text { 照度 } \\
(1 x)\end{array}$} & 3DCG & 1734 & 624 & 156 & 69.4 & 29 \\
\cline { 2 - 8 } & 実測 & 1976 & 837.7 & 234.7 & 80.4 & 44.1 \\
\hline \multicolumn{2}{l}{ 実測/3DCG 照度分析 } & 1.14 & 1.34 & 1.5 & 1.16 & 1.52 \\
\hline
\end{tabular}

(1) と同様に, 実測值の方が 3DCG 照度分析による照度值より全て高い $d=50 \mathrm{~cm}$ の時, 実測值の照度は $2 \sim 43 \%$ 高く, 光源に近い地点ほど值 の差が大きくなった. $d=100 \mathrm{~cm}$ の時, 実測值の照度は $18 \sim 33 \%$ 高く, 光源に近い地点ほど両者の值の差が大きくなった注 5).

3DCG 照度分析と実測値の差が生じる原因について, 照明の専門家 にヒアリングを行った結果を併せて整理する.

. 照明器具の光束値は, 基準值（公表值 $=3 \mathrm{DCG}$ 照度分析機能に使 用）と必ずしも同一ではなく，許容される範囲の最大值及び最 小值が存在する. 最大值と最小值の差を公差と呼ぶが, この值 は明らかでない。

照明器具の光束值は, 経年変化により新品の時点から徐々に減 少する．公表值はある時間断面の值であるため，実測值とは一 致しない可能性が高い.

・照度計算式並びに $3 \mathrm{DCG}$ 照度分析は光源を点光源として扱う。一 方, 実物の光源は厳密には面光源である. そのため, 光源近傍 では計算値と実測值に差が生じる可能性が高い.

· 床, 壁, 天井面からの間接光の影響.

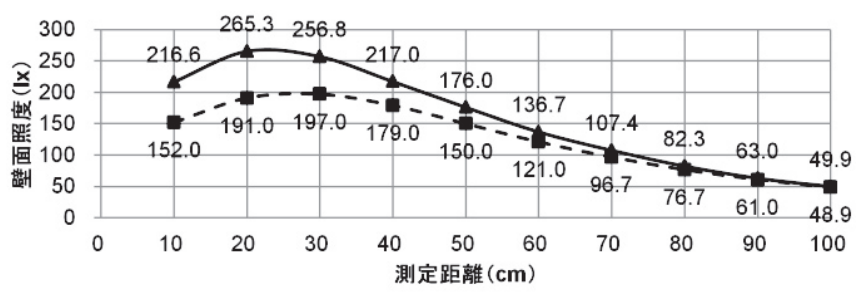

一—実測 - - -3DCG照度分析機能

図 83 DCG 照度分析と実測との比較（実験(2), $d=50 \mathrm{~cm}$ )

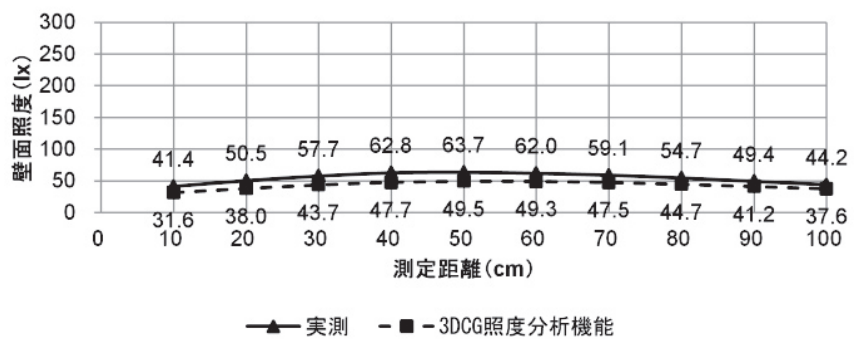

図 9 3DCG 照度分析と実測との比較（実験(2), $d=100 \mathrm{~cm}$ )

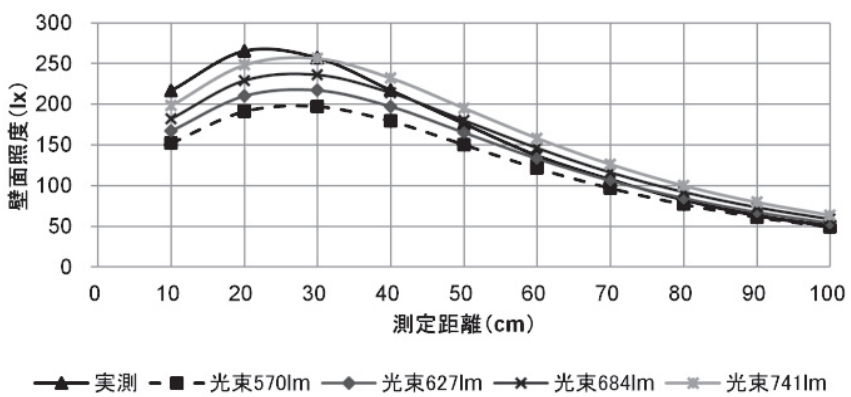

図 10 光束值の補正結果の比較 


\section{3 3DCG モデルに与える光束值の補正}

\section{(1) 実験概要}

3.2 節の結果より, AR 上で 3DCG モデルと実物の光源との照度值の 同一化を図るため, $3 \mathrm{DCG}$ 照度分析時に与える光束值を増加させて補 正する. 光束について, 公表值 $5701 \mathrm{~m}$ に係数 1. 1 1. 3 を乗じた值を 光束補正值として, 3.2 節 b) 実験(2)の 3DCG 分析を再実施する.

\section{(2) 結果}

結果を図 10 に示寸，照度值について，光源からの測定高さが 10 〜 $100 \mathrm{~cm}$ の間における 3DCG モデルの照度值を実測值で除した平均を 求めると, 公表值 $5701 \mathrm{~m}$ を使用した場合に 0.83 であるのに対して, 係数 1.1 （光束 $6271 \mathrm{~m}$ ）の場合に 0.91 , 係数 1.2 （光束 $6841 \mathrm{~m}$ ）の場 合に 1.0 , 係数 1.3 (光束 $7411 \mathrm{~m}$ ) の場合に 1.11 となった。值が最 も良好な係数 1.2 (光束 $6841 \mathrm{~m}$ ) の場合について, 測定高さ別に見る と, 光源に近い位置ほど $3 D C G$ モデルの照度值と実測值との差が大き くなる一方, 測定高さが $40 \mathrm{~cm}$ 以上の場合にはほぼ同値となることが 確認された。よって, 以降は光束 $6841 \mathrm{~m}$ として照度分析を行う注 6).

\section{4 色票を媒介とした AR 光学的整合性の検証 \\ 4.1 実験概要}

2 章で構築した色票システムを含むAR システム上に 3 章で検証し た照明効果付き $3 \mathrm{DCG}$ モデルを入力して, 実物の光源と同条件の $3 \mathrm{DCG}$ モデルとを並べて配置し, 光学的整合性の実現状況を検証する注7).

実験装置配置図を図 11 に示す。ディスプレイ 1 はAR 表示用であ りAR システムがインストールされている. また, ディスプレイ上部 には web カメラが水平視で設置されている. ディスプレイ 2 は AR マーカ用である. ディスプレイ 3 は色票 $\mathrm{CS}_{\mathrm{video}}$ 用である注 8$)$. ディス プレイ 3 と壁との間には実物の光源が設置されている. 尚, 壁の材 質はコンクリートであり, 白く塗られている.反射率は不明である.

色票 $\mathrm{CS}_{\mathrm{video}}$ と色票 $\mathrm{CS}_{\mathrm{cg}}$ との RGB 值 $\mathrm{RGB}_{\mathrm{cg}-255}$ と $\mathrm{RGB}_{\mathrm{video}-255}, \mathrm{RGB}_{\mathrm{cg}-127}$ と $\mathrm{RGB}_{\mathrm{video}-127}, \mathrm{RGB}_{\mathrm{cg}-0}$ と $\mathrm{RGB}_{\mathrm{video}-0}$ をそれぞれ同值化させる作業の間, 光源は消灯状態である. 次に, 色票 $\mathrm{CS}_{\mathrm{video}}$ と色票 $\mathrm{CS}_{\mathrm{cg}}$ とが同值化さ れた後，光源を点灯させ，AR 表示された $3 \mathrm{DCG}$ モデルと実写映像と の RGB 值を観察する。その際，AR 映像をスクリーンキャプチャし， 画像処理ソフトを用いて光源からの一定間隔別に RGB 值を測定する.

同值化作業を行う際には, 2.2 節で示したパラメータが色票 $\mathrm{CS}_{\text {video }}$ の RGB 值に影響を与えるが，組み合わせが膨大となるため，予備実 験を通じて各パラメータ值の絞込みを検討した。まず，色票 $\mathrm{CS}_{\text {video }}$ を表示するディスプレイ 3 の輝度レベルは 0 ～8 9 9 段階に変更が可 能であるが, 輝度レベルが高いと色票 $\mathrm{CS}_{\mathrm{video}}$ の RGB 值が $\mathrm{RGB}_{\mathrm{video}-0}=0$ を示さなくなり，輝度レベルが低いと色票 $\mathrm{CS}_{\mathrm{video}}$ の RGB 值が $\mathrm{RGB}_{\mathrm{video}-255}=255$ を示さなくなることが観察された. そのため, ディ スプレイ 3 の輝度レベルは中間值の 4 と 5 を採用した。次に, web カメラのパラメータである明るさ，コントラスト，ガンマ，露出の 内, 露出は最大值（1）で固定した. 明るさ，コントラスト，ガンマ については, RGB 值計測システムを使用して計測される $R_{\text {GGB }}{ }_{\mathrm{cg}-255}$, $\mathrm{RGB}_{\mathrm{cg}-127}, \mathrm{RGB}_{\mathrm{cg}-0}, \mathrm{RGB}_{\mathrm{video}-255}, \mathrm{RGB}_{\mathrm{video}-127}, \mathrm{RGB}_{\mathrm{video}-0}$ の計測結果を観 察しながら, $\mathrm{RGB}_{\mathrm{cg}-255}$ と $\mathrm{RGB}_{\mathrm{video}-255}, \mathrm{RGB}_{\mathrm{cg}-127}$ と $\mathrm{RGB}_{\mathrm{video}-127}, \mathrm{RGB}_{\mathrm{cg}-0}$ と $\mathrm{RGB}_{\mathrm{video}-0}$ とが可能な限り同值となるように調整する。また, web カメラと色票 $\mathrm{CS}_{\mathrm{video}}$ を表示する液晶ディスプレイとの成す角度によ っても RGB 值は変化する注 9). 本実験では, web カメラと色票 $\mathrm{CS}_{\mathrm{video}}$
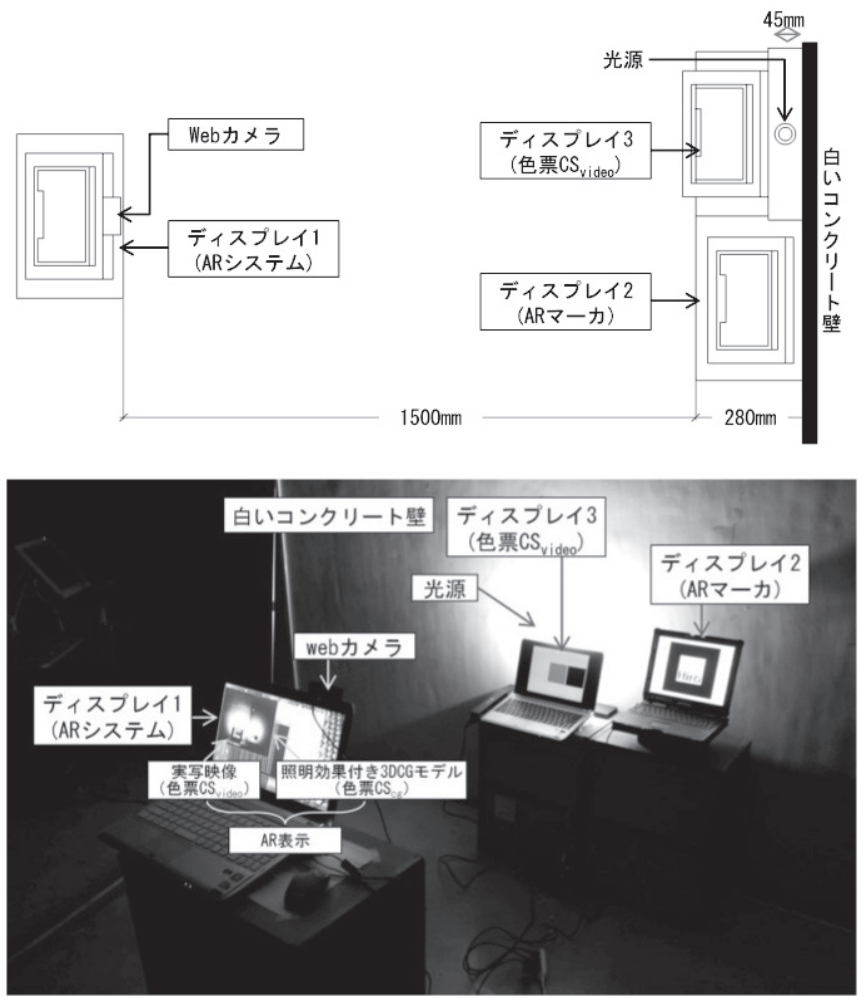

図 11 実験風景 (上: 平面図, 下: 写真)

を表示するディスプレイ 3 との成す角度は $10^{\circ} ， 20^{\circ} ， 30^{\circ}$ の 3 パ ターンを設定した。これらの組み合わせにより下記の 4 ケースを設 定した。

ケース $1:$ ディスプレイ 3 の輝度レベルは 4 , web カメラとディ スプレイ 3 との成す角度は $10^{\circ}$, web カメラの明るさ 10 , コン トラスト 15 ，ガンマ 105

ケース $2:$ ディスプレイ 3 の輝度レベルは 4 , web カメラとディ スプレイ 3 との成す角度は $10^{\circ}$, web カメラの明るさ 10 , コン トラスト 15, ガンマ 110

ケース $3:$ ディスプレイ 3 の輝度レベルは 4 , web カメラとディ スプレイ 3 との成寸角度は $20^{\circ}$ ，web カメラの明るさ 10 ，コン トラスト 20 , ガンマ 160

ケース 4 : ディスプレイ 3 の輝度レベルは 5 , web カメラとディ スプレイ 3 との成す角度は $30^{\circ}$, web カメラの明るさ 10 , コン トラスト 20 , ガンマ 160

\section{2 結果と考察}

\section{（1）色票の同値化の状況}

色票 $\mathrm{CS}_{\mathrm{cg}}$ と色票 $\mathrm{CS}_{\mathrm{video}}$ の RGB 值の結果を表 3 に示す. 2.3 節で示 した通り, 各色票の中心点の周囲 64 画素の RGB 值（0-255）を抽出 し, 各色票について, 平均值を $\mathrm{RGB}_{\mathrm{cg}-255}, \mathrm{RGB}_{\mathrm{cg}-127}, \mathrm{RGB}_{\mathrm{cg}-0}, \mathrm{RGB}_{\mathrm{video}-255}$, $\mathrm{RGB}_{\mathrm{video-127}}, \mathrm{RGB}_{\mathrm{video}-0}$ とした。 $\mathrm{RGB}_{\mathrm{cg}}$ はいずれのケースも $\left(\mathrm{RGB}_{\mathrm{cg}-255}\right.$, $\left.\mathrm{RGB}_{\mathrm{cg}-127}, \mathrm{RGB}_{\mathrm{cg}-0}\right)=(255,127,0)$ となった． $\mathrm{RGB}_{\mathrm{video}}$ は液晶ディス プレイに表示された人工マーカをweb カメラでキャプチャするため, 各画素の $\mathrm{RGB}$ 值の標準偏差が大きくなった。また, $\mathrm{RGB}_{\mathrm{cg}-255}$ と $\mathrm{RGB}_{\mathrm{video}-255}, \mathrm{RGB}_{\mathrm{cg}-127}$ と $\mathrm{RGB}_{\mathrm{video}-127}, \mathrm{RGB}_{\mathrm{cg}-0}$ と $\mathrm{RGB}_{\mathrm{video}-0}$ の值が完全に 一致するケースは現れなかったものの， $\mathrm{RGB}_{\mathrm{video}}$ の三色票の合計と $\mathrm{RGB}_{\mathrm{cg}}$ の三色票の合計との差の絶対值は, $4 \sim 19$ と小さな值を示した. 
特にケース 3 の差は 4 と最小であり, 同值化はほぼ達成していると いえる.

表 3 色票 $\mathrm{CS}_{\mathrm{cg}}$ と色票 $\mathrm{CS}_{\mathrm{video}}$ の $\mathrm{RGB}$ 值

\begin{tabular}{|c|c|c|c|c|c|c|}
\hline & & & ケース 1 & ケース 2 & ケース 3 & ケース 4 \\
\hline \multirow{4}{*}{$\begin{array}{c}\mathrm{R}=\mathrm{G}=\mathrm{B} \\
=0 \\
(\text { 黑) }\end{array}$} & \multirow[b]{2}{*}{$\mathrm{RGB}_{\text {video }}$} & 平均 & 0 & 0 & 3 & 3 \\
\hline & & 標淮偏差 & 0 & 0 & 0 & 0 \\
\hline & \multirow[b]{2}{*}{$\mathrm{RGB}_{\mathrm{cg}}$} & 平均 & 0 & 0 & 0 & 0 \\
\hline & & 標淮偏差 & 0 & 0 & 0 & 0 \\
\hline \multirow{4}{*}{$\begin{array}{c}\mathrm{R}=\mathrm{G}=\mathrm{B} \\
=127 \\
(50 \% \\
\text { (灰) }\end{array}$} & \multirow[b]{2}{*}{$\mathrm{RGB}_{\text {video }}$} & 平均 & 128 & 140 & 128 & 105 \\
\hline & & 標準偏差 & 3 & 2 & 3 & 2 \\
\hline & \multirow[b]{2}{*}{$\mathrm{RGB}_{\mathrm{cg}}$} & 平均 & 127 & 127 & 127 & 127 \\
\hline & & 標準偏差 & 0 & 0 & 0 & 0 \\
\hline \multirow{4}{*}{$\begin{aligned} R=G=B & =255 \\
= & \text { (白) }\end{aligned}$} & \multirow[b]{2}{*}{$\mathrm{RGB}_{\text {video }}$} & 平均 & 247 & 255 & 255 & 255 \\
\hline & & 標準偏差 & 2 & 0 & 0 & 0 \\
\hline & \multirow[b]{2}{*}{$\mathrm{RGB}_{\mathrm{cg}}$} & 平均 & 255 & 255 & 255 & 255 \\
\hline & & 標淮偏差 & 0 & 0 & 0 & 0 \\
\hline \multicolumn{3}{|c|}{ 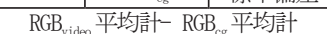 } & -7 & 13 & 4 & -19 \\
\hline
\end{tabular}

\section{（2）実物光源と $3 D C G$ モデルの光学的整合性の実現状況}

壁の反射率が不明であるため，4.1 節で設定した 4 つのケースに ついて，3DCG モデルの壁面反射率毎（25\%，30\%，50\%，60\%，70\%， 80\%, 90\%, 100\%) にAR 映像を作成して, スクリーンキャプチャする. 作成された AR 画像に対して光源から一定間隔 $(50 \mathrm{~mm})$ 毎に RGB 值を 測定する.これにより, 実物光源と 3 DCG モデルの光学的整合性の実 現状況を検証する. 測定地点として, 光源から垂直方向 $(0 \sim 550 \mathrm{~mm}$. サンプル点 12$)$, 光源上空 $250 \mathrm{~mm}$ から水平方向 $(0 \sim 300 \mathrm{~mm}$. サンプ ル点 7）とした。測定の状況を図 12 に示す.

垂直方向と水平方向を総合した結果を図 13 に示す. 反射率別に, 19 のサンプル点で得られた 3DCG モデルと実写映像との差の平均值 を下に示す. 文献 ${ }^{22)}$ において, 白壁の反射率は 55\%〜 75\%とある. そのため，ケース 3-反射率 60\%（0.1），ケース 3-反射率 70\%（2.7） が妥当な数值であると考えられる.ケース 3 -反射率 $60 \%$ の AR 光学的 整合性の実現状況を図 14 に示寸. 目視観察においても光学的整合性 は実現しているといえ, $\mathrm{CS}_{\mathrm{cg}}$ と $\mathrm{CS}_{\mathrm{video}}$ の RGB 值が同值であるならば, 3DCG モデルと実写映像の光学的整合性は実現することを確認した.

最後に, AR システムによる光の再現度合いについて, 実験室に配 置された照明を目視した場合と, 照明が webカメラを通じてディス プレイに表示された場合を比較すると, ディスプレイ表示では照明 の輝度（まぶしさ）が目視の場合ほど強くない。これは実験に用い たディスプレイのダイナミックレンジが目視に比べて小さいためで あると考えられる. この解決の一方策として, ダイナミックレンジ のより大きいディスプレイの使用, 光学透過ヘッドマウントディス プレイの使用が考えられる. 光学透過ヘッドマウントディスプレイ は, 実空間の照明光源を直に眺めながら, その手前に $3 D C G$ モデルを 重畳させることができるため, 目視に近い状態でAR シミュレーショ ンが可能になると予想される注10).

\section{5 結論と今後の課題}

\section{1 結論}

本研究は, AR で照明シミュレーションを行う際に必要となる, 3DCG モデルと実写映像との光学的整合性の実現手法について検討 した.このため, 実物の白色光源と同条件の 3DCG モデルを同時に AR 表示させ, 3DCG モデルと実写映像の RGB 值の同值化を検討した. その際, 実際の照明シミュレーションの現場では, 実物の光源を用

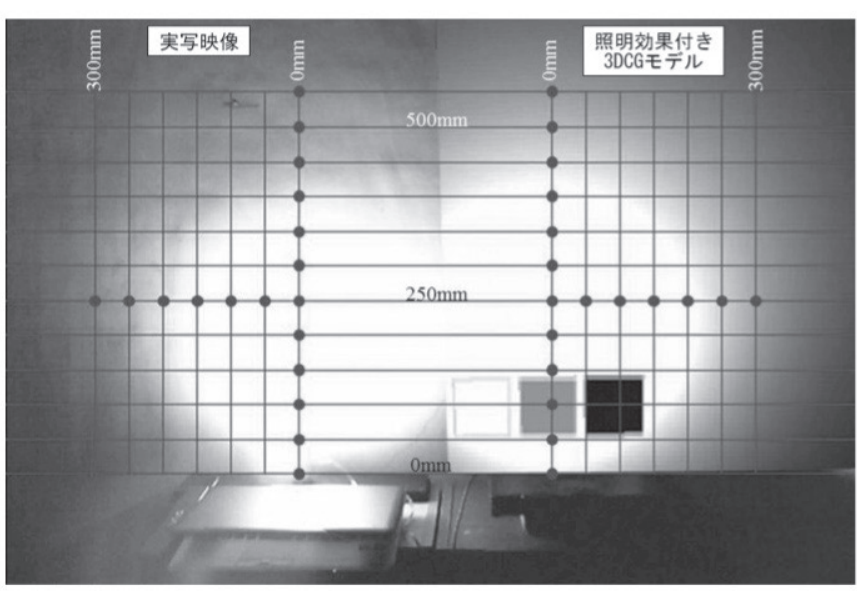

図 12 測定の様子(円印: 測定点)

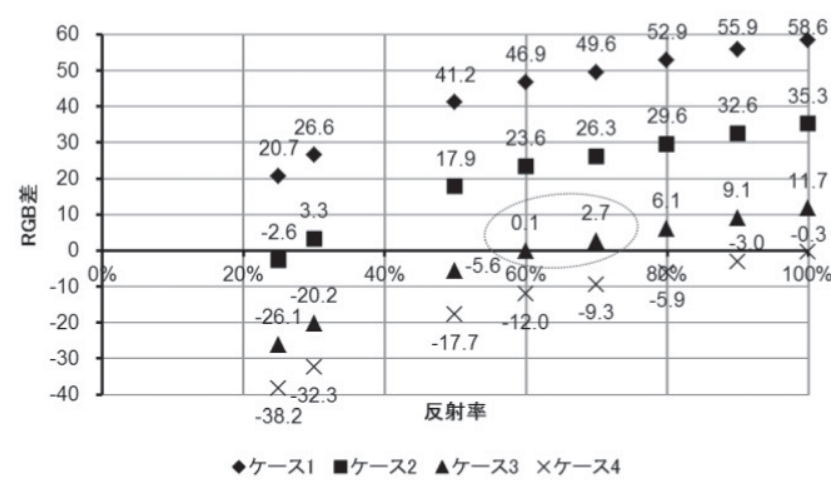

図 13 3DCG モデルと実写映像との差の平均值（総合）
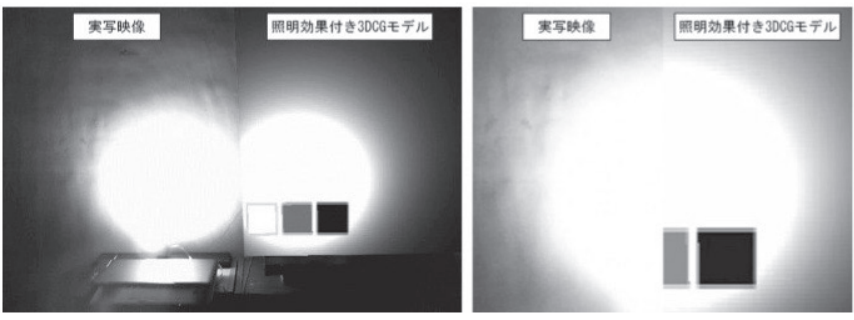

図14 AR 画面キャプチャ（左）と拡大表示（右） (ケース 3-反射率 60\%)

意することは稀であるため, 3DCG モデルと実写映像の媒介として色 票システムを提案した. 本研究の成果を以下に示す.

構築した AR システムは, 照明効果付き 3 DCG モデルを入力する ことが可能であり照明シミュレーションに適用可能である。ま た, 内照式の人工マーカを採用しているため, 夜間のような低 照度の空間でも利用可能である.

AR システムに入力する照明効果付き $3 \mathrm{DCG}$ モデルは, 3DCG モデ ルが点光源に近似されること, 公表されている光束值には公差 が存在すること等の理由により, 実測值と照度值の差が存在す る. 3DCG モデルは実測值よりも常に低い值を示しており, 係数 1.2 を乗じて補正すると照度はほぼ同值となることを確認した。 3 段階の RGB 值を有する色票システムを構築して, 3DCG モデル の色票 $\mathrm{CS}_{\mathrm{cg}}$ と, 実空間を実写映像として AR 表示する色票 $\mathrm{CS}_{\mathrm{video}}$ との RGB 值の同值化に成功した，その際，パラメータである $\mathrm{CS}_{\text {video }}$ を表示するディスプレイの輝度レベルは 4 , web カメラと ディスプレイ 3 との成寸角度は $20^{\circ}$, web カメラの明るさ 10 , 
コントラスト 20 , ガンマ 160 , 壁面反射率 $60 \%$ におて, 実物光 源と 3DCG モデルとの RGB 值差は 0.1 であった. すなわち, 3DCG モデルと実写映像との光学的整合性は実現しているといえる.

\section{2 今後の課題}

本研究では, 一種類の LED 光源のみを対象としており, 他の点光 源や面光源について検証できていない. 3.3 節に示した補正の程度 は光源ごとに異なることが考えられるため, データベース化が求め られる.また, 光源として白色のみを扱ったため作成した色票はグ レースケールとした。しかしながら実際には電球色など有彩色の光 源も存在する. 今後は様々な色温度の光源とそれに対応する色票の 検討を行う必要がある. 次に, 本研究で構築した AR システムでは, 照明シミュレーションされた $3 D C G$ モデルの照明効果を実写映像領 域に及ぼすことはできない。すなわち, AR システムの適応対象は, 照明設計の影響が 3DCG モデルの領域内に収まる場合に限られる. 3DCG モデルの照明効果を実写映像領域に及ぼすことが可能なシス テムを開発し, 適応対象を拡げることが求められる. 今後の課題と したい.

\section{注}

注1）現状では，夜間景観設計分野において VR 上でリアルタイム代替案を生 成することは直接光の定義に留まる。

注2）使用した光源，ソフトウェアは 3.1 節で述べた内容と同じである. 以下 の実験も同様.

注3）実験日時は2011年 7 月 8 日 $18: 00 \sim 19: 00$, 場所は大阪大学吹田キャ ンパス S4-111 講義室（W=10.0m, D=18.7m, H=3.2m）である. 照度を測 定寸る壁面はコンクリートであり, 白く塗られている. 反射率は不明で ある。それ以外の壁面は $5 \mathrm{~m}$ 以上離れており間接光の影響は限りなく小 さい. 床面は白色のタイルであるが反射の影響を抑えるため黒色の布マ

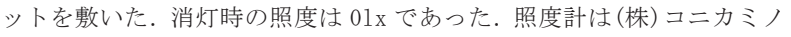
ルタ製 T-10を使用した。

注4）実験日時は 2011 年 10 月 7 日 $10: 30 \sim 12: 00$, 場所はパナソニック電工 （株）照明環境評価大暗室（W=5. $5 \mathrm{~m}, \mathrm{D}=7.5 \mathrm{~m}, \mathrm{H}=11.84 \mathrm{~m}$ ）である（社名 は当時). 大暗室には空がなく, 照射される一面が白色である他の三面 は黒カーテンで覆われている，床面は濃い灰の絨毯である．消灯時の照 度は $01 \mathrm{x}$ であった。照度計は(株)コニカミノルタ製 $\mathrm{T}-10$ を使用した。

注5）実測照度値と $3 D C G$ 照度分布による照度值のズレに関して, 昼光を対象 とした既往研究 ${ }^{21}$ では, 実測とシミュレーションの值には 1.4 倍の差が あると報告されている.人工照明のみを対象とした両者のズレに関する 既往研究は見当たらない, 一般の照度設計では, 机上面や床面照度を検 討するため, 光源-照度面距離は 3.2 節の実験で対象としたような $100 \mathrm{~cm}$ 以下の距離以上になると考えられる. $100 \mathrm{~cm}$ 以上の場合, 両者のずれは 無視できるほど小さくなることは 3.2 節で確認済みである。一方, AR システムを用いた照明検討シーンでは, 光源近傍の照明影響などを検討 することも考えられるため 3.2 節の実験形態とした。尚, 本研究の限界 として, 他の点光源や面光源での検証はできていない. また, 3.3 節で 示したような補正の方法は, 各光源により異なることも考えられデータ ベース化を進める必要がある。これらは今後の課題に記述した。

注6）本研究で実施したような平均值による光束值の補正方法による精度向 上以上に実測值に近づけるためには, 光束值に加え配光曲線を補正する 必要がある. しかし, 3 次元で定義される配光曲線の各パラメータを操 作して実測值に近づけるには膨大な試行錯誤が必要であるため, 本研究 では光束值のみの補正とした。尚, 5 章に示した通り, 本研究では, 3 DCG モデルと実写映像との RGB 差はほぼ同值であることを示せており（図 13), 現在のAR システムで得られる精度は光束值のみの補正で十分であ ると考えられる.

注7）実験日時は 2012 年 1 月 30 日 $18: 00 \sim 26: 00$, 場所は大阪大学吹田キャ ンパス S4-111 講義室である. 実験室, 照度計の条件は, 注 3 と同じで ある。

注8）本研究では, ディスプレイ 3 (色票表示用), Web カメラのデバイスはそ れぞれ, ディスプレイ 3 (ソニー製 VAI0 VPCS13AGJ), web カメラ (エ
レコム製 UCAM-DLX300BK）と一般の市販品を用いている.他の市販品を 用いた場合に最適なパラメータを新たに確認する必要は生じるが, 本研 究で示した手順で同様の再現性は可能であると考える.

注9）照明 AR シミュレーションでは 4 章で述べた実験のように，低照度の空 間での検討が多いと考えられるため, 色票は内照式が有効であると考え られる. 一方, 本研究で使用した PCディスプレイは設置角度により web カメラから見た時の色票の RGB 值が変化してしまい, キャリブレーショ ンの手間が増えた。これは, 用いた PC ディスプレイが液晶ディスプレ イである上にプライバシー保護の観点から斜め方向からの視認性を低 下させているためである. あらゆる方向から眺めた時に同じRGB 值とな る内照式色票は技術的には可能であるため, この課題解決に向けて検討 する必要がある.

注10) 光学透過ヘッドマウントディスプレイは研究開発が進められているが, 本研究実施時点では, 性能面とコスト面で課題が多いと判断したため採 用していない，光学透過ヘッドマウントディスプレイの利用により，本 研究で用いた web カメラは少なくとも不要となるため, 4.1 節で述べた パラメータの組合せを隇らすことにも寄与できると考える.

\section{参考文献}

1) T. Fukuda, R. Nagahama, A. Kaga, S. Oh, T. Sasada: Collaboration Support System for City Plans or Community Designs based on VR/CG Technology, International Journal of Architectural Computing, Issue 04, Volume 01, pp. 461-469, 2003. 12.

2) T. Fukuda, R. Nagahama, A. Kaga, S. Oh, T. Sasada: Collaboration Support System for Nightscape Design based on VR Technology, Proceedings of The 7th International Conference on Computer Aided Architectural Design Research in Asia (CAADRIA2001), pp.103-111, 2001. 4 .

3) T. P. Viet, C. S. Yeon, W. S. Hak, C. Ahrina: AR: An Application for Interior Design, Proceedings of The 14th International Conference on Computer Aided Architectural Design Research in Asia (CAADRIA2009), pp. 116-124, 2009. 4.

4) Charles, W., Mika, H., Otto, K., Tuomas, K., Miika, A., Kari, R., Kalle, K. : Mixed Reality for Mobile Construction Site Visualization and Communication, Proceedings of the 10th International Conference on Construction Applications of Virtual Reality (conVR2010), pp. $35-44,2010.11$.

5) N. Yabuki, K. Miyashita, T. Fukuda: An invisible height evaluation system for building height regulation to preserve good landscapes using augmented reality, Automation in Construction, Volume 20, Issue 3, pp. 228-235, 2011.3.

6) S. Watanabe: Simulating 3D Architecture and Urban Landscapes in Real Space, Proceedings of The 16th International Conference on Computer Aided Architectural Design Research in Asia (CAADRIA2011), pp. 261-270, 2011. 4.

7） 中林拓馬, 加戸啓太, 平沢岳人：拡張現実感と模型を用いた建築設計用 ッールの開発，日本建築学会技術報告集，17，37，pp. 1053-1056， 2011. 10.

8) N. Yabuki, Y. Hamada, T. Fukuda: Development of an accurate registration technique for outdoor augmented reality using point cloud data, 14th International Conference on Computing in Civil and Building Engineering (ICCCBE2012), 2012.6.

9) T. Fukuda, T. Zhang, Y. Yabuki: Availability of Mobile Augmented Reality System for Urban Landscape Simulation, 9th International Conference, CDVE (Cooperative Design, Visualization, and Engineering) 2012, pp. 231-238, 2012.9.

10）池内克史, 佐藤洋一, 西野恒, 佐藤いまり : 複合現実感における光学的 整合性の実現, 日本バーチャルリアリティ学会論文誌 4(4), pp. 623-630, 1999. 12.

11）神原誠之, 横矢直和 : 光源環境の実時間推定による光学的整合性を考慮 したビジョンスペース拡張現実感, 電子情報通信学会技術研究報告, 102 (555), pp. 7-12, 2003.

12）冨手要, 藤木真和, 麻生隆: 複合現実感における影の光学的整合性に関 する検討とレイトレーシングによる実現，情報処理学会研究報告， 2008(3), pp. 75-80, 2008.

13）角田哲也, 大石岳史, 池内克史：影付け平面を用いた複合現実感におけ 
る高速陰影表現手法, 映像情報メディア学会誌, Vol. 62, No. 5, pp. 788-795, 2008.

14）小川拓也, 倉持元陽, 山本昇志 : 物体の影からの光源推定を用いた複合 現実感の生成, 映像情報メディア学会技術報告, Vol. 35, No. 8, pp. 139-142， 2011.

15）仁科勇作，奥村文洋，神原誠之，横矢直和：適応的なハイダイナミック レンジ画像合成による拡張現実感のための光源環境推定，情報処理学会 研究報告, 2008(3), pp. 185-190，2008.

16）篠田博之, 山口秀樹: 色モード境界輝度による視環境の明るさ評価, 照 明学会誌, 93(12), pp. 885-891，2009. 12 .

17）山口秀樹, 篠田博之: 色モード境界輝度による空間の明るさ感評価, 照 明学会誌, 91 (5), pp. 266-271, 2007.5.

18）加藤博一, M. Billinghurst, 浅野浩一, 橘啓八郎：マーカ追跡に基づく 拡張現実感システムとそのキャリブレーション, バーチャルリアリティ 学会論文誌 Vol.4, No4，pp. 607-616，1999.12.
19) HITLab : ARToolkit Home Page, http://www. hitl.washington. edu/ artoolkit/, （参照 2012.9.25）

20) OpenCV.jp: opencv samples and documents, HITLab : ARToolkit Home Page, http://opencv. jp/, （参照 2012.9.25）

21）栗木茂，大阪谷彰，三浦寿幸，村江行忠：高空を有する小学校の室内照 度分布の実測とシミュレーションの比較, 日本建築学会大会学術講演梗 概集 D-1，pp. 581-582，2008.9.

22) 平山嵩: 建築学大系 22 室内環境計画「新建築学大系 22$\rfloor, 1969$.

23）林緯政，福田知弘，矢吹信喜：AR を用いた夜間景観シミュレーションの ための光学的整合性の実現に向けた基礎的研究, 日本建築学会・情報シ ステム技術委員会第 34 回情報・システム・利用技術シンポジウム論文集 (報告)，pp. 175-178，2011.12.

24）福田知弘，林緯政，矢吹信喜：AR を用いた照明シミュレーションのため の光学的整合性の実現手法に関する研究, 平成 24 年度日本建築学会近畿 支部研究報告集，第 52 号環境系，pp. 17-20, 2012.6. 